\title{
Revisiting the Anti-Hazing Law in Selected Higher Education Institutions in Nueva Ecija, Philippines: A Policy Review
}

\author{
Arneil G. Gabriel${ }^{1}$, Teodora Luz Mangahas ${ }^{2}$ \\ ${ }^{1}$ Department of Public Administration, Nueva Ecija University of Science and Technology, Cabanatuan City, Philippines \\ ${ }^{2}$ Department of Social and Behavioral Sciences, Nueva Ecija University of Science and Technology, Cabanatuan City, Philippines \\ Email: opats14@yahoo
}

How to cite this paper: Gabriel, A.G. and Mangahas, T.L. (2016) Revisiting the AntiHazing Law in Selected Higher Education Institutions in Nueva Ecija, Philippines: A Policy Review. Open Access Library Journal, 3: e3177.

http://dx.doi.org/10.4236/oalib.1103177

Received: October 27, 2016

Accepted: November 18, 2016

Published: November 21, 2016

Copyright () 2016 by authors and Open Access Library Inc.

This work is licensed under the Creative Commons Attribution International License (CC BY 4.0).

http://creativecommons.org/licenses/by/4.0/

c) (i) Open Access

\begin{abstract}
Hazing is a serious social problem. It wasted not only the lives of future and promising leaders of society but also their aspirations for their families. The study is an evaluation of the implementation of the Anti-Hazing Law. 80 Student Organization Members and Officers (SOMO) and 20 Student Affairs Professionals (SAP) from four (4) universities in Nueva Ecija, Philippines are interviewed. From the point of view of the respondents, five (5) variables related to the implementation of the antihazing law are measured using measure of central tendency and percentile ranking. They are: a) monitoring of organizational meeting; b) monitoring of student organization activities; c) accreditation and recognition of student organizations; d) university initiative on resolving organizational conflicts and e) involvement of alumni and parents in student organizations program for development. The findings showed that SOMO and SAP rated sometimes in the first variable and often on the second and third variables; sometimes on the last two variables. Both the SOMO and SAP exhibited "awareness" on the anti-hazing law. In view of the findings of the study, a clear and comprehensive anti-hazing prevention policy and education campaign among SOMO is recommended.
\end{abstract}

\section{Subject Areas}

Education, Law, Politics, Social Issues and Public Policy

\section{Keywords}

Hazing, Student Organizations, Higher Education Policy in the Philippines, Policy Review 


\section{Introduction}

\subsection{Background and Its Setting}

Hazing is a serious social problem. It wasted not only the lives of future and promising leaders of society but also their aspirations for their families. The death of Leonardo Lenny Villa in 1991 created a strong public demand to put an end to Hazing [1]. The demand exerted by public and private educational institutions created a stream of political pressure to the $13^{\text {th }}$ Congress of the Philippines to put an end to the senseless killing by making it a priority legislative agenda. The Congress through, Senator Joey Lina eventually enacted Republic Act 8049 also known as the Anti-Hazing Law of 1995. After 21 years of implementation, the law is now ripe for evaluation.

The purpose of the law is not to prohibit initiation rites but to regulate it. Republic Act 8049 has two main intentions to wit; a) to declare the act of hazing as mala prohibita [2]; b) to regulate the practice of initiation rites among student organizations, fraternities, sororities and military training establishments. The mala prohibita principle imposes upon any person or group of individual stiffer penalty when used as a prerequisite for membership to student organizations: a) physical, b) social, c) emotional, and d) psychological tests. The law also sought not to declare as illegal the holding of initiation rite. Its intention is to regulate the manner student organizations undertake initiation ritual.

The International Covenant on Civil and Political Rights (1966) of the United Nations condemned hazing [3]. As a universally accepted principle of international law, the State is duty bound to protect the life, liberty and property of its citizens. As a State signatory, the Republic of the Philippines must comply with her obligation to the covenant in good faith. The operation of the pacta sun servanda doctrine [4], as a norm of international conduct, binds the Philippine government to give life and spirit to the covenant by transforming the covenant a domestic law through the application of the provision of the Constitution of making universally accepted principle of international law as part of the law of the land [5].

To protect its citizens, RA 8049 or the Anti-Hazing Law was enacted. The Commission on Higher Education (CHED) issued Memo Number 4 series of 1995 imposing stiffer penalty upon student organization members proved to commit hazing and other forms of violence in campus. It also mandated the Higher Education Institutions (HEI) to assume full responsibility and the duty to monitor student organizations and their activities [6].

\subsection{Filling the Gap in Knowledge}

There is a dearth of local literature on hazing. The sensitivity of the issue and the prevailing subculture of silence and secrecy among student organizations made the issue impenetrable to many. The records inaccessible to researchers except those filed in court. Strengthened by the prevailing culture of violence and" code of secrecy" among student organization members, cases of hazing are placed beyond the bounds of scientific inquiry. Not to mention the "machismo culture" prevailing among organization 
members. Hazing becomes a myth amidst reality. This is the gap that the study would like to fill in. On the contrary, foreign literature shows stunning difference. Recent studies on student organizations proved their involvement in campus violence specifically Greek-letter organizations [7]). And if the trend continues, the very reason for the establishment of school system finds no relevance [8]. In the beginning, student organizations like fraternities and sororities are known for promoting good values of democracy, loyalty, respect, service, scholarship and morality [9]. The founding fathers of these organizations established them for benevolent and noble intentions [10]. Nowadays, student organizations are known for influencing the campus culture of hazing, substance abuse, poor scholastic performance, and other illegal activities [11].

The increasing decay of student organization culture encourages violence and hazing as determinant of the applicant qualification to join or the "rite to passage". According to Arnold Jr. of Tennessee State University [12], the level of awareness of student affairs personnel and their attitudes toward hazing are important factors to solve this social problem. Thus, treating hazing as a concern only of Greek-letter organizations in post secondary schools would make the problem worse [13]. The lack of monitoring allows commission of hazing among varsity teams, military training centers and school societies. Studies also showed that hazing takes place not only in Greek-letter society but also in military organization, high school clubs, society and even among professional organizations [14]. Accordingly, Henessy and Hudson recommends that an anti-hazing policy must be incorporated to institutional policies.

\subsection{Objectives of the Study}

The RA 8049 also known as the Anti-Hazing Law is now in its implementation stage and nearing the policy termination phase. This study contributes not only to the body of knowledge on the issue but also a step toward assessing the efficacy of the old RA 8049. The general objective of the study is to measure the level of understanding and the degree of implementation of RA 8049 in selected Higher Education Institutions in Nueva Ecija using as basis of analysis the perspectives of Student Organization Officers and Members and Student Affairs Professionals. The measured variables can be deduced from the following objectives, to wit;

1) To describe the profile of Student Organization Members and Officers.

2) To describe the SOMO and their pre-membership experiences in relation to RA 8049 .

3) To measure the selected universities observance of RA 8049 based on the perspectives of Student Affairs Professionals (SAP) and Student Organizations Officers and Members (SOMO) in terms of the following.

a) Monitoring of student organizations' meetings.

b) Monitoring of student organization activities.

c) Implementation of the requirements for recognition and accreditation of student organizations.

d) Institutional initiative to solve inter-organizations conflict encouraging hazing. 
e) Parents participation in student organizations, activities and development program.

5) To measure the level of awareness of SOMO and SAP on RA 8049.

\section{Research Methods}

\subsection{Research Design}

The study used the descriptive research in policy evaluation of RA 8049. It is suitable to the study considering the nature of the subject and the difficulty of acquiring data or records in the library and government offices. The qualitative-descriptive approach will not only describe "what" but inquire into "why" and "how" of the subject of inquiry [15]. After pre-testing the instrument for validity, survey questionnaires were distributed to the different universities in Nueva Ecija. The instrument has four main parts: a) the part for the respondents profile; b) pre-membership experiences; c) institutional policies on student organizations measured in five dimensions; and the last part consisting of the d) measurement of the level of awareness of student organization members and officers and student affairs professionals on RA 8049.

\subsection{Data Gathering Technique and Sampling Method}

Aside from the questionnaires used as the means to gather data, focus group discussion (FGD), direct actual observation, documentary analysis and interview were also used. It applied the percentile and measure of central tendency as statistical treatments. Purposive sampling method was use to select 80 Student Organization Officers and Members (SOMO) from different universities and 20 Student Affairs Professionals (SAP). The criteria applied for the purposive sampling for students-respondents are as follows: a) must be a member or officer of student organization for at least two years; b) must be enrolled during the current year; c) must be willing to give consent to the interview; d) must be actively involved in organization activities in the past 6 months. The locale of the study is in Nueva Ecija, Philippines. The cooperating universities are: a) Nueva Ecija University of Science and Technology, in Cabanatuan City, a state university; b) Central Luzon State University in Science City of Munoz, likewise a state managed higher institution of learning; c) Araullo-Phinma Education Network and d) Wesleyan University-Philippines both in Cabanatuan City and private universities.

\section{Conceptual Framework}

The simple David Easton's policy analysis model was used to guide the interpretation, structure and analysis of data [16]. Thus, the study treats the implementation of RA 8049 as the selected universities' SAP and SOMO concern. The study considers the observance of existing institutional policies on student organizations and activities, and the objectives of the RA 8049 as the parameters to measure its implementation and served as the inputs. These inputs are processed by the universities to ensure safety and security of students from hazing related activities. The five institutional policies on student organizations and activities and the degree of observance by the selected uni- 
versities, would create an output of a hazing free campus. This output in the long run creates institutional impact on safety and security of students from hazing inside and outside the school premises. The model and the variables are shown in Figure 1, to wit.

As the research paradigm, the study argues that systems approach serves as the guiding structure for the analysis and structure of the study. It begins with the perspectives of the Student Organizations Members and Officers and Student Affairs Professionals as inputs to the study. These inputs are processed as the study variables are measured and descriptively evaluated according to the groups' perceptions. The five (5) variables and the awareness of the respondents are treated with the statistical tool of frequency distribution thereby, creating a response pattern and research output in the form of policy review. It is noteworthy, that the throughput phase effectively involves the four (4) universities for effective implementation. The research output shall again form part of the feedback loop which may serve as new inputs to the policy makers whether or not to amend or revise RA 8049. The cycle of input-throughput-output continues.

\section{Results and Discussion}

\subsection{Profile of Respondents}

There are two sets of respondents namely: a) student organization members and officers (SOMO) student affairs professionals (SAP). Student Affairs Professionals are employees of the universities assigned to manage student organizations regardless of their nature. There are several categories of student organizations. They are the interest

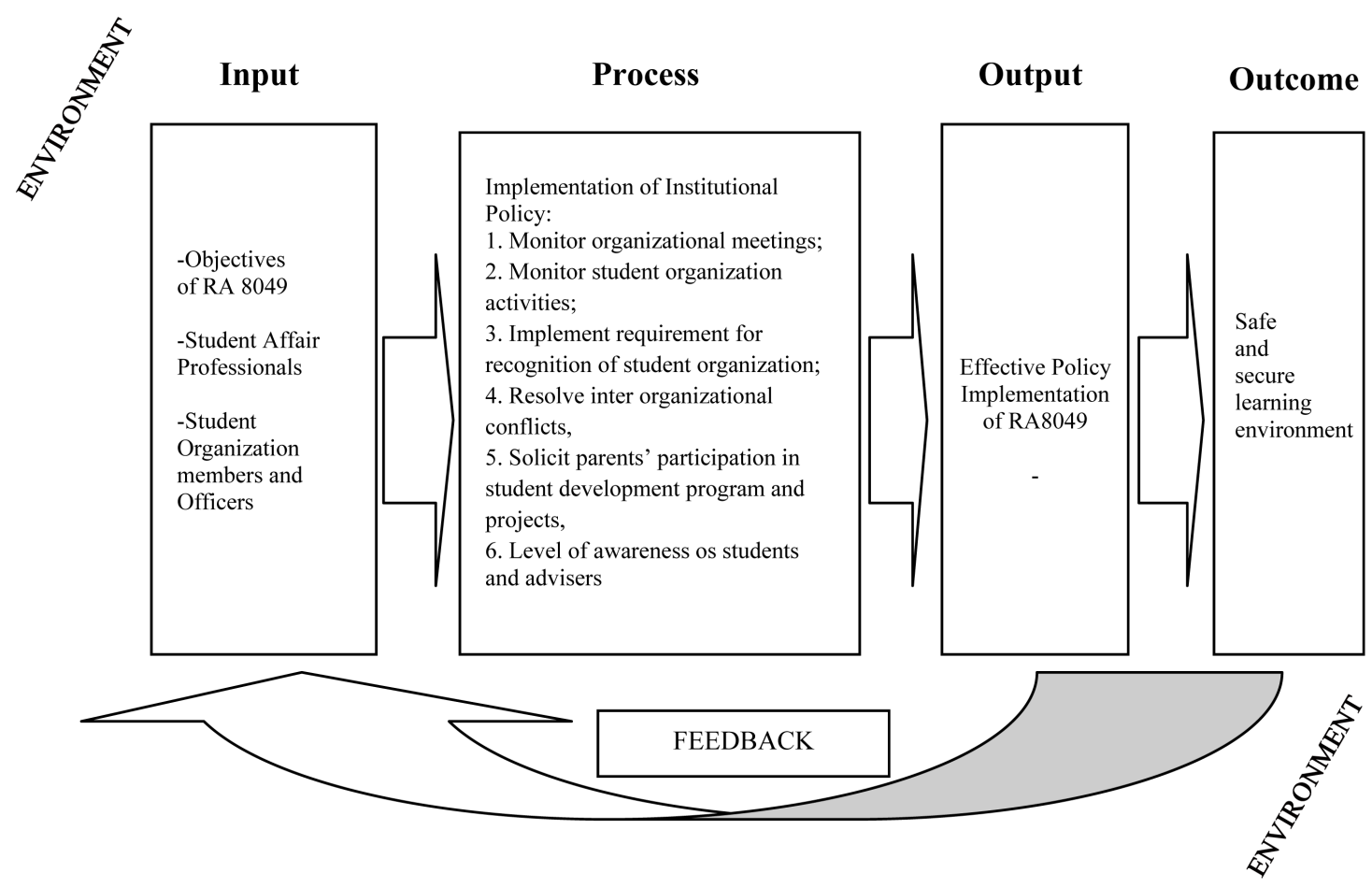

Figure 1. Systems model of policy process adopted from W. I. Jenkins, policy analysis. 
groups where cause oriented, academic and civil society groups belong. The group consists of fraternities and sororities known to many as the Greek-lettered organizations. The data showed that majority of the respondents-students come from interests groups. Only twenty percent (20\%) are members of fraternity and sorority. Eleven (11) or 14\% of the respondents are below age of majority of 18 years old. The majority of student-respondents aged eighteen (18) and above. Majority of the members are female (60\%) while the remaining $40 \%$ belong to female gender. Table 1 shows the profile of the respondents, to wit.

The above table leads to the following assertions:

Some of the respondents are minors. Other than the application of RA 8049, RA 7610 or the Anti-Child Abuse Law may be violated if these minors are made to undergo hazing.

Surprising however is the fact that age of minority which prevents students from joining student organizations regardless of its nature is not observed by the respondents as it may appear that eleven (11) of the respondents are minors but are already active members of organizations. Sixteen or $20 \%$ of the respondents belong to collegiate fraternal organizations while sixty-four (64) of the respondents are members of interest groups. The readings on policies show that Student Handbook of the respondent schools prevent students at age of minority, to enter any type of student organization.

\subsection{Profile of Student Affairs Professionals}

Majority of the Student Affairs Professionals (SAP) are serving the universities for quite a long time ranging from one (1) year to ten (10) years equivalent to seventy five percent $(75 \%)$ of the respondents across universities. Meanwhile, data showed that the greater majority of the respondents are males accounting to $60 \%$ of the entire population while the female counterpart constituting only forty percent (40\%).

The results of the study are presented in Table 2 to wit.

Table 1. Profile of student organizations members and officers across universities.

\begin{tabular}{ccccccc}
\hline \multirow{2}{*}{ SOMO } & \multicolumn{2}{c}{ Age } & \multicolumn{2}{c}{ Sex } & Nature of Student Organizations \\
\cline { 2 - 6 } & $\begin{array}{c}\text { Below 18 } \\
\text { years }\end{array}$ & $\begin{array}{c}18 \text { years } \\
\text { above }\end{array}$ & Male & Female & Interest Groups & $\begin{array}{c}\text { Fraternity and } \\
\text { Sorority }\end{array}$ \\
\hline $14 \%$ & $\begin{array}{c}86 \% \\
(69)\end{array}$ & $\begin{array}{c}40 \% \\
(32)\end{array}$ & $\begin{array}{c}\text { (3) } \\
(11)\end{array}$ & $(48)$ & $80 \%$ & $20 \%$ \\
$(16)$
\end{tabular}

Table 2. Profile of student affairs professionals.

\begin{tabular}{cccccccccc}
\hline \multirow{2}{*}{$\boldsymbol{c}$ Age } & \multicolumn{3}{c}{ Agex } & \multicolumn{4}{c}{ Years in service } \\
\cline { 2 - 9 } & 30 and below & $31-40$ & $41-50$ & Male & Female & $1-5$ & $6-10$ & $11-15$ & $15-20$ \\
\hline $35 \%$ & $45 \%$ & $20 \%$ & $60 \%$ & $40 \%$ & $25 \%$ & $50 \%$ & $25 \%$ & $25 \%$ \\
7 & 9 & 4 & 12 & 8 & 5 & 10 & 5 & 0 \\
\hline
\end{tabular}




\subsection{On Pre-Membership Experiences}

The principal element to violate RA 8049 law is when the acts prohibited are committed as prerequisites for membership in the different student organizations including military establishment. Table 3 presents the description of respondent pre-membership experiences, to wit;

Table 3 provides the data on the pre-membership experiences of student organizations, officers and members. From a multiple checklist questionnaire, we require the respondents to check the situations provided in the questionnaire if and when they were forced to undergo during their neophyte stage. Based on the data, some of the student organization members experienced hazing while entering the organization. The" yes "responses correspond to the overall total of responses to situations described in the questionnaires as acts of psychological, physical, social humiliation and emotional tests described in RA 8049. The accumulated total of 309" yes "answers" imply that the tests mentioned were imposed upon them during their pre-membership stage in student organizations. Thus, the result tends to show that some student organizations are committing violation of RA 8049 provisions. This finding intensifies the need to know the level of their understanding of the law itself and how the student organizations and student affairs professionals observed RA 8049.

\subsection{Observance of Institutional Policies to Prevent Hazing}

Meanwhile, Table 4 showed the responses of SOMO on five variables in relation to administration policies to prevent hazing per university. On the part of SOMO, university 2 has the lowest compliance level in terms of monitoring of organizational meeting while university 1 provides the highest level of compliance on monitoring of meeting and student membership. On the other hand university 4 has the highest degree of implementation observance of institutional policies on hazing in relation to CHED Memorandum Circular Number 4 series of 2014; having all the responses as" often" in the first four variables while showing "sometimes "in the area of parents participation in student organization development program. The respondents are also aware of the implementation of RA 8049. In addition, the following findings are essential, to wit:

1) On the point of view of SOMO, organizational meeting and assembly had an overall weighted mean of 3.46 or "often"; 2) As to monitoring of student activities, 3.29 or "sometimes"; 3) On recognition and accreditation of student organization, a weighted mean of 3.54 or "often"; 4) On university's involvement in resolving conflict, an overall weighted mean of 3.31 or "sometimes"; 5) On participation of alumni and parents, an overall weighted mean of 3.1 or "sometimes"; 6) On the level of student awareness on

Table 3. Pre-membership experiences.

\begin{tabular}{ccc}
\hline & Pre-membership experiences \\
\hline & Yes responses & No responses \\
\hline SO MO & 309 & 843 \\
\hline
\end{tabular}


Table 4. Summary table of responses of student respondents to five variables and measurement of their level of awareness on RA 8049.

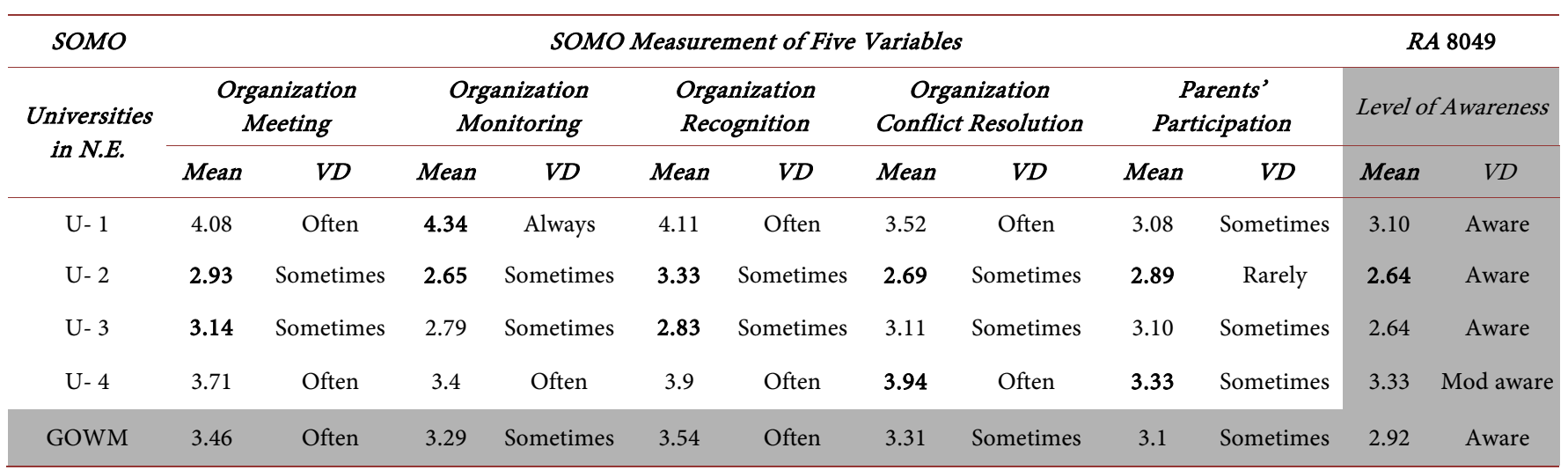

RA 8049; the respondents revealed low level of awareness corresponding to a weighted mean of 2.92 or "aware".

Meanwhile, the succeeding Table 5 represents the counterpart responses of SAP which reveal that:

On the perspective of SAP among the five variables involving the prevention of hazing, the variable on student organization recognition is considered as consistent. In fact, they rated themselves as" often" which means that recognition of student organizations is regularly observed. It is noteworthy that recognition of students' organization not only motivates them to do good in campus but also provides the university updated data on the operation of student organizations and the personal background of their members. They are data useful to track the membership in case they commit violence and hazing. It is also noteworthy that many of the universities especially privately owned ones do not recognize fraternities and sororities. Based on interview among the generic term student organization, it is only Greek lettered organizations that universities are reluctant to recognize. Only one among the four (4) universities recognizes the existence of Geek lettered association. This implies that in some other universities, they operate beyond the monitoring of the administrators. Thus, it provides greater chances of committing hazing during recruitment and initiation rites. The finding leads us to the question of priority in student organization management. Non recognition of Greek Lettered Society is in effect, a violation of their right to self-organization which is secured and its enjoyment ensured under a democratic government. Nonetheless many Greek letter societies are not recognized by respondent universities. There seems to be a clash between the right to organize and the duty of the higher education institution to ensure peace and order inside the campus as its breached is ordinarily committed by fraternal organizations specifically hazing activities.

The succeeding Table 6 showed the summary of responses of SOMO and SAP on the observance of the 5 variables necessary to prevent hazing, to wit:

1) On Organizational meeting and assembly an Overall Weighted Mean of 3.27 or "sometimes" was obtained; 2) On monitoring of student activities, an Overall Weighted Mean of 3.85 or "often" was obtained; 3) On recognition and accreditation of student 
Table 5. Summary table of student affairs professionals on five variables and their measurement of the level of awareness on hazing.

\begin{tabular}{|c|c|c|c|c|c|c|c|c|c|c|c|c|}
\hline \multirow{3}{*}{$\begin{array}{c}S A P \\
\text { Selected } \\
\text { Universities } \\
\text { in N.E. }\end{array}$} & \multicolumn{10}{|c|}{ SAP Measurement of Five Variables } & \multicolumn{2}{|c|}{$R A 8049$} \\
\hline & \multicolumn{2}{|c|}{$\begin{array}{l}\text { Organizational } \\
\text { Meeting }\end{array}$} & \multicolumn{2}{|c|}{$\begin{array}{l}\text { Organization } \\
\text { Monitoring }\end{array}$} & \multicolumn{2}{|c|}{$\begin{array}{l}\text { Organization } \\
\text { Recognition }\end{array}$} & \multicolumn{2}{|c|}{$\begin{array}{c}\text { Organization } \\
\text { Conflict Resolution }\end{array}$} & \multicolumn{2}{|c|}{$\begin{array}{c}\text { Parent's } \\
\text { Participation }\end{array}$} & \multicolumn{2}{|c|}{ Level of A wareness } \\
\hline & Mean & $V D$ & Mean & $V D$ & Mean & $V D$ & Mean & $V D$ & Mean & $V D$ & Mean & $V D$ \\
\hline $\mathrm{U}-1$ & 3.55 & Often & 3.83 & Often & 3.91 & Often & 2.33 & Rarely & 2.83 & Sometimes & 3.45 & Aware \\
\hline $\mathrm{U}-3$ & 4.08 & Often & 3.76 & Often & 3.12 & Sometimes & 3.48 & Often & 3 & Sometimes & 3.08 & Aware \\
\hline $\mathrm{U}-4$ & 4.48 & Always & 4.58 & Always & 4.69 & Always & 4.5 & Always & 3.92 & Often & 4.04 & Mod aware \\
\hline G O WM & 3.27 & Sometimes & 3.85 & Often & 4.18 & Often & 3.54 & Sometimes & 3.2 & Sometimes & 2.92 & Aware \\
\hline
\end{tabular}

Table 6. Summary of the grand weighted mean scores of SOMO and SAP perspectives on five measured variables.

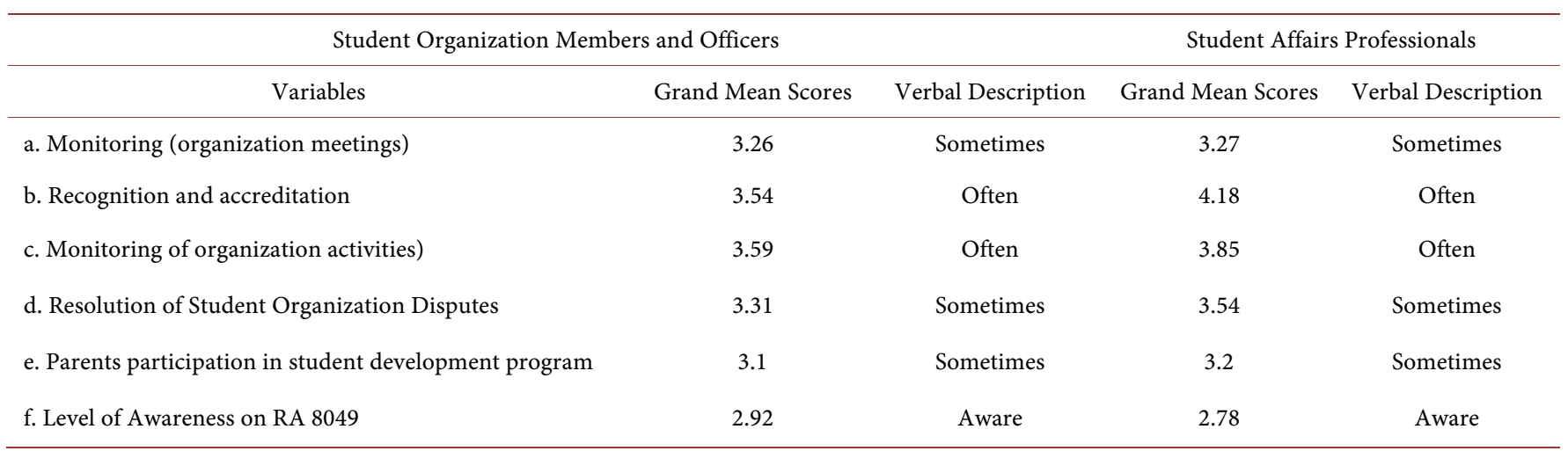

organizations an Overall Weighted Mean of 4.18 or often; 4) On university involvement in the resolution of conflict yielded an Overall Weighted Mean of 3.54 "sometimes"; 5) On participation of alumni and parents in student organizations program of development, an Overall Weighted Mean of 3.2 was obtained and interpreted as "sometimes"; 6) On the level of awareness of student affairs professional on RA 8049, a weighted mean of 2.92 or "aware" was obtained.

The table showed that across universities, they implement the policy on monitoring student organizations' meetings, having a pair of weighted mean scores of 3.26 and 3.27 respectively. However, it should be noted that the implementation of policy is not subject to discretion. If the responses gathered are within the range of verbal description of "sometimes", then it is safe to conclude that sometimes they forego its observance. On the recognition and accreditation of student organizations, a verbal description of "often "shows that the universities observed the requirements for recognition. In terms of frequency, it is safe to conclude that among the institutional policies it is in this area that students and student affairs professionals are morally convinced that implementation is necessary. The weighted mean scores are 3.54 and 4.18 respectively. The Table also reveals that parents and alumni and the university administration participate in conflict resolution involving student organizations. A weighted mean of 3.1 for the 
student affairs professionals and 3.2 for student organizations and members suggest that both the parents and the university as stakeholders to the development of students were "sometimes" solicited. This finding however will have greater value to students and the university if done regularly. Research studies showed that student affairs professionals may tap the support of parents to implement student disciplinary program. The strengthened linkage with the parents and alumni of student organization members and the university would create a positive learning environment essential to prevent hazing activities.

\section{Conclusions}

In view of the above findings, the following conclusions are respectfully submitted:

1) The students' organizations under consideration sometimes overlooked the prohibition on institutional policy on recruiting students at age of minority.

2) The student organizations under consideration did not fully comply with the provisions of RA 8049.

3) The SAP interviewed and responded showed that they are not fully conscious of the importance of observing RA 8049 as measured by the laxity in the observance of institutional policies on student organizations management.

4) The respondents' student organizations (SOMO) have low level of awareness of the provisions of RA 8049.

It is argued that the effectiveness of a public policy rests on effective implementation. Public policy is made either to secure justice or protect citizens from injustice. But when the implementation of public policy lies on the discretion of implementing authority, it tends to make an otherwise effective policy into a useless codification of legal principles. Senator Joey Lina once said: "The law is only as good as it is implemented". The question now is this, do we need to amend or revise RA 8049 ? The study believes that neither of the two is necessary. What is needed is an effective implementation. Student government of different universities should sponsor a comprehensive awareness campaign and the study may be replicated in other universities in the Philippines to level of understanding and observance of the law. Or it may be too late.

\section{Acknowledgements}

We would like to thank the four universities' Student Affairs Officers, without their support the researchers could not finish the study for insufficiency of data.

\section{References}

[1] Villa vs Escalona; Supreme Court of the Philippines. www.gov.ph/directory

[2] Reyes, L.B. (2011) The Revised Penal Code of the Philippines. Rex Bookstore, Manila.

[3] United Nations Covenant on Civil and Political Rights. United States, New York.

[4] Bernas, Q.G. (2002) Introduction to Public International Law. Rex Printing Company Incorporation, Manila.

[5] The 1987 Philippine Constitution .Official Gazzette, Office of the President Republic of the 
Philippines.

[6] Commission on Higher Education Memorandum Circular Number 4, Series of 1995. http://www.ched.gov.ph/central/page/ched-condemns-recent-death-by-hazing-of-another-l aw-student

[7] Perkins, A. and Zimerman, D. (2011) Changing Trends in the Undergraduate Fraternity/ Sorority Experiences: An Evaluative and Analytical Literature Review. Oracle, 6, 57-73.

[8] Zacharda, C.S. (2009) How Peer Leadership Impacts Hazing in the Arena of Non Revenue Income Generating College Athletics. Unpublished Masters Degree Thesis, Rossier Education, University of Southern California, Los Angeles.

[9] American Association State Colleges and University Annual Report (2005). www.aascu.org

[10] Sterner, R. (2008) The History of Hazing in American Higher Education. https://ruthsterner.files.wordpress.com/2008/05/histpdf.pdf

[11] Arnold Jr., W. (2005) A Comparison of Hazing Attitudes in Student Affairs Professionals at Selected Historically Black Learning Institutions of Higher Education in Tennessee University. Unpublished Doctoral Dissertation.

[12] Nueva Ecija University of Science and Technology Student Handbook, 2001.

[13] Allan, E.J. and Madden, M. (2008) Hazing in View: College Students at Risk. http://www.stophazing.org/wp-content/uploads/2014/06/hazing in view web1.pdf

[14] Arnold, J.C. (1995) Alcohol and the Chosen Few: Organizational Reproduction in an Addictive System. Unpublished Doctoral Dissertation. https://books.google.com.ph/books?id=GqA8LUTFs6EC\&pg=PA177\&lpg=PA177\&dq=Ar nold,+J.C.+(1995)+Alcohol+and+the+Chosen + Few:+Organizational+Reproduction + in + an + Addictive+System. + Unpublished + Doctoral+Dissertation.\&source=bl\&ots $=$ YSumLd6HvT \&sig=66evk3VPYj7 uKNZMy4MZQeVkrw\&hl=en\&sa=X\&ved=0ahUKEwiVjIXxjqzQAhX Di5QKHV6JBk0Q6AEIGzAA\#v=onepage\&q=Arnold\%2C\%20J.C.\%20(1995)\%20Alcohol\% 20and\%20the\%20Chosen $\% 20$ Few $\% 3$ A $\% 20$ Organizational\%20Reproduction $\% 20 \mathrm{in} \% 20 \mathrm{an} \%$ 20Addictive $\% 20$ System.\%20Unpublished\%20Doctoral\%20Dissertation.\&f=false

[15] Mariano, A.M. (2006) Principles and Methods of Research. Rex Bookstore Incorporation, St. Manila.

[16] Hill, M. (1997) The Policy Process: A Reader. Prentice Hall, Hemel Hempstead.

\section{Submit or recommend next manuscript to OALib Journal and we will provide best service for you:}

- Publication frequency: Monthly

- 9 subject areas of science, technology and medicine

- Fair and rigorous peer-review system

- Fast publication process

- Article promotion in various social networking sites (LinkedIn, Facebook, Twitter, etc.)

- Maximum dissemination of your research work

Submit Your Paper Online: Click Here to Submit

Or Contact service@oalib.com 